autonomic ganglia. Langley applied nicotine to ganglia in order to determine the effect of stimulating the cells present in the ganglia. Recently, attention has been directed to various peripheral effects of nicotine at sites where ganglia are not present. Thus, nicotine has a two-fold effect in the isolated heart. It causes first inhibition of contractions, and second acceleration and augmentation. The inhibition is excluded in the presence of atropine, but the acceleration is unaffected. In the heart there is a store of noradrenaline which can be extracted from the heart. Hitherto the existence of this store has been neglected by physiologists. It is now evident that the acceleration of the heart caused by nicotine is due to the release of some of the noradrenaline from the store. This follows from the observation that when there is no store of noradrenaline, nicotine loses its accelerating action (Burn and Rand, Oxford). Treatment of the animal with reserpine causes a disappearance of the store at the end of a few hours. The rise in heart-rate which follows smoking is thus probably explained by an action of nicotine on the heart itself releasing noradrenaline from storage sites in the heart.

In 1940 it was shown by Grace Roth and her colleagues that when a person smoked a cigarette in a warm room there was a large fall in skin temperature. This fall was believed to result from a constriction of the skin vessels caused by a stream of impulses passing down the vasoconstrictor nerves. However, observations have recently been made in the isolated ear of the rabbit, which contains no ganglia. These have shown that when the vessels of the ear are perfused with a modified Ringer's solution, the outflow being measured with a sensitive recorder, the injection of $3 \mu \mathrm{gm}$. of nicotine into the fluid about to enter the ear causes vasoconstriction. The outflow from the ear veins is greatly reduced. This action also appears to be due to the release of noradrenaline from a store present in the ear, either in the walls of the vessels or in tissue nearby. For if a rabbit is injected with reserpine on one day, and then killed on the following day, the noradrenaline which can be extracted from the skin of the ear has disappeared, and when the ear is perfused with
Ringer's solution, nicotine no longer causes vasoconstriction. When the skin of such an ear is extracted, no noradrenaline is found present in it. Some individuals suffer from a disease called thrombo-angiitis obliterans which when active causes such a restriction of the circulation through the fingers that the tissues become dry and bloodless, and the finger tips may become gangrenous. The disease may be quiescent for long periods; but if the patient begins to smoke, the symptoms get worse and the disease becomes active. It seems likely that the effect of smoking is explained by nicotine releasing noradrenaline from the neighbourhood of the small vessels.

The exact site of storage of noradrenaline in the heart and in or near the vessels is unknown. There is a possibility that it is held in tissue known as chromaffin tissue. These are cells which stain brown with potassium dichromate; they form the greater part of the cells of the adrenal medulla. Such cells have long been known to occur among the fibres of the sympathetic system, and side by side with the sympathetic ganglion cells. They originate in the neural crest like the sympathomimetic ganglion cells and were called by Kohn "paraganglia" in 1903. Evidence is beginning to accumulate that the distribution of chromaffin cells is much wider. Busacchi in 1912 deseribed a "paraganglion cardiacum" lying around the origins of the coronary arteries. AdamsRay and Nordenstam (1956) have described such cells in human skin, and Leach believes that they may be present in the skin of the rabbit ear, in the skin of the cat's tail and in the nictitating membrane of the cat's eye. In all these situations nicotine exerts an action on the normal tissue. Thus, as already mentioned, nicotine causes constriction of the vessels of the rabbit ear; it also causes erection of the hair on the cat's tail, and finally it causes contraction of the nictitating membrane when isolated from the body and free from ganglia. Yet if an animal is previously treated with reserpine, and if in consequence all local stores of noradrenaline disappear, nicotine loses these actions, and all the chromaffin cells are lost. It may therefore be that nicotine exerts its peripheral effects by discharging noradrenaline from chromaffin cells.
J. H. BuRN

\title{
THE NEW ZEALAND ANTARCTIC EXPEDITION
}

$\mathrm{I}^{\mathrm{N}}$ the thirty-third Thomas Cawthron Memorial Lecture, Sir Edmund Hillary described some of the experience gained by members of the New Zealand Antarctic Expedition (Cawthron Institute, Nelson, New Zealand. Thomas Cawthron Memorial Lecture No. 33 (1958) : The New Zealand Antarctic Expedition. By Sir Edmund Hillary. Pp. 12+4 plates. Nelson: Cawthron Institute, 1959). AIthough, for economy, the expedition made use of Ferguson tractors, Sir Edmund records that, with three 'Snocats', the journey could have been done "with twice the comfort and in almost half the time".

Comparison of the buildings which have been traditionally used on British expeditions and the newer module type of construction shows the advantages to rest almost entirely with the latter.

The experience gained with the dog teams should be of value to other expeditions. At the base, the dogs lived primarily on seal meat supplemented by vitamin pills, although this was varied at times with tinned dog food. In the field lightness was of primary importance and here pemmican was used. There were two forms of pemmican. One was the standard 'Bovril' pemmican which has been used a great deal in the Antaretic and the Arctic. Long and strenuous trips have been made on this pemmican, but the literature on the subject is filled with criticisms of it and descriptions of the deterioration in dog health when it is used. The Expedition's experience with 'Bovril' pemmican was much the same--loss of condition and continual scouring. "It was very fortunate that we also had generous supplies of the second type of pemmican, which was based on a formula developed by Dr. Malcolm of the Otago Medical School for the Byrd Expedition'. 'This pemmican proved to be an outstanding success and 
played an important part in the achievements of the dog teams. The formula is :

$\begin{array}{lr}\text { Meat meal } & 42 \text { per cent } \\ \text { Tallow } & 40 \text {," } \\ \text { Whole wheat meal } & 10 \text {,", } \\ \text { Wheat germ } & 5 \text {,", } \\ \text { Molasses } & 2 \text {," }\end{array}$

Sir Edmund Hillary indicates that dogs can still do a useful task in the Antarctic. The expedition made it clear that dogs eannot compete with vehicles when travelling long distances or hauling profitable payloads. While the average man can quickly adapt himself to driving a tractor in snow, a dog driver and his team need long and constant training and practice to reach a pitch of proficiency. Although the men did extremely well, at no stage could they have reached the standard of skill shown by the professional drivers in a party such as Amundsen's.

But a dog team is a mobile form of transport and can give useful support to a survey or geological party in rough or crevassed country. If the dog teams are airlifted to the area to be explored, and if they are kept supplied by air so that they can travel with reduced loads and so move briskly about, they are probably still the best form of transport for a close examination of the many great mountain ranges and glaciers which fringe the barren wastes of the polar plateau.

\title{
RADIOCAESIUM AND POTASSIUM-40 IN NORWEGIAN-PRODUCED MILK
}

\author{
By K. MADSHUS and J. BAARLI \\ Norsk Hydro's Institute for Cancer Research, Oslo, Norway
}

$\mathrm{T}$ $\mathrm{HE}$ radioactive isotopes cæsium-137 and strontium-90 represent a major part of the radiation hazard to man caused by nuclear explosions, by reason of their long half-lives (28 and 27 years, respectively). The rate of fall-out depends to a large extent on the geographical locality, and on the weather conditions at the relevant places of interest ${ }^{1,2}$. There is evidence that the northern hemisphere and places with high rate of precipitation ${ }^{3}$ receive the highest fall-out. These conditions obviously hold for Norway.

The degree of hazard which the ionizing radiation represents to man can, in principle, be estimated in two ways. One method is to determine the amounts of the isotopes in foodstuffs, taking into account the discriminating factors involved during passage of the food through the human body. The other method is the direct measurement of radiation from the human body. Milk appears to be one of the main constituents of the human diet carrying the radioactive material from the ground into the human body.

The present work was undertaken to obtain as reliable information as possible about the concentration of cæsium-137 in Norwegian-produced milk. This isotope is most important in view of the genetic effects of its $\gamma$-radiation $\left(E_{\gamma}=660 \mathrm{keV}\right.$.), compared with the more localized damage caused by the B-radiation from strontium-90 $\left(E_{\beta}=0.61 \mathrm{MeV}.\right)$.

It seems an established fact ${ }^{4}$ that the fall-out ratio strontium-90/cæsium-137 from atom-bomb debris is nearly constant. This is not only the case for soil and rain-water; milk samples collected within the same districts also show the same tendeney $^{5}$. As the experimental determination of crsium-137 is a rapid process compared with the more laborious determination of strontium-90, the content of cæsium-137 can servo as a quick monitor of the rate of strontium-90 fall-out.

The equipment used for studies of low-level $\gamma$-radia tion has been described elsewhere ${ }^{6}$. It is composed of a heavily shielded scintillation detector, consisting of a sodium iodide (thallium) crystal $2 \frac{1}{2}$ in. diameter $\times$ 3 in. and a Du Mont 6363 phototube in connexion with an R.C.L. 256-channel pulse-height analyser.
A cross-section of the equipment is shown in Fig. 1. The background radiation in the measuring space of this equipment is found to be $212 \pm 1 \cdot 0$ counts $/ \mathrm{min}$. in the energy-range $80-1,700 \mathrm{keV}$. The background, in the two pulse-height regions of special interest to the present study, is $14 \cdot 1 \pm 0 \cdot 1$ counts $/ \mathrm{min}$. in the cæsium-137 photopeak range, and $5 \cdot 3 \pm 0 \cdot 1$ counts min. in the potassium-40 peak. The position of the photopeak in the pulse-height spectrum is stable over a long period, being 0.75 per cent after the initial warm-up. The equipment has been calibrated using dried milk with a known concentration of cæsium-137 and potassium-40. The samples were canned in metallic containers, each holding $250 \mathrm{gm}$. of dried milk. We are much indebted to Dr. D. V. Booker, of the Atomic Energy Research Establishment, Harwell, for supplying us with several of his measured samples used here for calibration purposes.

Two kinds of standards were used, one containing full-cream dried milk, and the other skimmed dried milk. The calibration samples contained 670 pc./ $\mathrm{kgm}$. and $485 \mathrm{pe} . / \mathrm{kgm}$. of cæsium-137 $\left(1 \mathrm{pe} .=10^{-12}\right.$ curie) with a potassium content of 14.9 and 17.6 $\mathrm{gm}$. $/ \mathrm{kgm}$. for the skimmed milk, and $445 \mathrm{pc}$. eæsium$137 / \mathrm{kgm}$. and $11 \cdot 2 \mathrm{gm} . / \mathrm{kgm}$. for the full-cream dried milk.

Dried skimmod milk and full-cream dried milk were obtained from a dairy receiving milk from districts in the Tröndelag and Hedmark counties. The former county lies in central Norway, near the coast. It is one of the greatest farming districts in the country. Hedmark lies in south-east Norway, about 300 miles from the west coast.

The individual samples were taken from batches of about 22,000 1. Each sample contained $250 \mathrm{gm}$. of dried milk, the same as the standard sources used for ealibration. The canning was also identical. Measurements of samples were carried out over periods of $4 \mathrm{hr}$. or more. Background and calibration runs were made from time to time. No significant variations in the number of counts stored in the cæsium-137 and potassium-40 photopeaks, exceeding the statistical errors, were observed. No radioactivity which could be attributed to radio-elements other 